
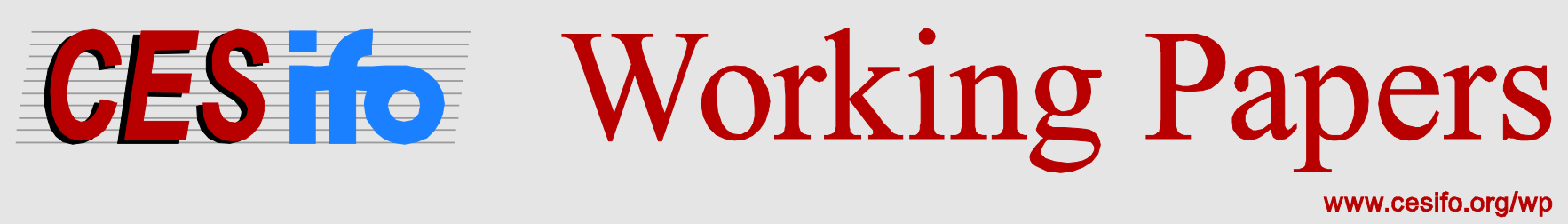

\title{
The Long Arm of the European VAT, Exemplified by the Dutch Experience
}

\author{
Leon Bettendorf \\ Sijbren Cnossen
}

\author{
CESIFO WORKING PAPER NO. 4730 \\ CATEGORY 1: PUBLIC FinANCE \\ MARCH 2014
}
An electronic version of the paper may be downloaded
- from the SSRN website:
- from the RePEc website:
- from the CESifo website:
wWw.SSRN.com
www.RePEc.org
www.CESifo-group.org/wp

\section{CESifo}




\title{
The Long Arm of the European VAT, Exemplified by the Dutch Experience
}

\begin{abstract}
The European Commission is evaluating the performance of the common VAT, which has many shortcomings. The numerous exemptions and differentiated rate structures violate the logic and functionality of the VAT. The exemptions distort input choices and outsourcing policies. Reduced rates are ill-targeted tools for mitigating the regressivity of the VAT. In view of these design shortcomings, the EU VAT is in danger of becoming an anachronism compared with modern VATs elsewhere. This paper illustrates its shortcomings with reference to the Dutch experience. The paper does not break new ground, but provides a disconcerting picture of the excess burden of a major revenue source. Bold reform is indicated.
\end{abstract}

JEL-Code: H210, H230, H250.

Keywords: VAT, European Union, exemptions, reduced rates.

Leon Bettendorf

CPB Netherlands Bureau for Economic Policy Analysis

The Hague / The Netherlands

l.j.h.bettendorf@cpb.nl
Sijbren Cnossen*

CPB Netherlands Bureau for Economic

Policy Analysis

The Hague / The Netherlands

cnossen@ese.eur.nl

*corresponding author 


\section{Introduction}

In 1967, the six founding member states of the European Economic Community (EEC for short; subsequently merged into the European Union (EU)) agreed to the adoption of a common value added tax (VAT), primarily to ensure that border tax adjustments for exports and imports between member states would be effected unambiguously, which was not possible under the old cumulative turnover taxes. This move was followed in 1977 by agreement on a common base and basic administrative procedures. The common VAT, ${ }^{1}$ which is a condition for EU membership, has hardly been changed since 1977. Change is difficult, because it requires the unanimous consent of all 28 member states.

By contrast, the economic conditions in the world have changed considerably, as exemplified by the enormous increase in the services trade, the introduction of the internet, and the globalization of entrepreneurial production - all developments that should affect the design and operation of the VAT. Further, the EU VAT does not reflect the experience of countries with modern VATs (often called goods and services tax, or GST for short), such as Australia, Canada, New Zealand, Singapore, and South Africa. The VATs in these countries have a broad base with very few exemptions and mostly a single rate. This is in line with the widely-held view that the VAT is primarily a revenue-raising instrument, not designed to manipulate the distribution of the tax burden or achieve some other non-tax purpose.

This situation led the European Commission to publish a Green Paper in 2010, entitled On the Future of VAT: Towards a Simpler, More Robust and Efficient VAT System. In that paper, the Commission highlights the numerous shortcomings of the EU VAT and proposes to review its coherence in light of the internal market and its efficiency as a revenue-raising instrument and to develop ways to reduce compliance costs. In response to the paper, a large number of studies, commissioned by the Commission, have been published and various conferences organized. With the findings of these studies in mind, this paper evaluates the Dutch VAT, which is modeled on the EU VAT. Following a brief analysis, the paper focuses mainly on the economic and administrative problems of exemptions and rate differentiation.

\section{Analysis of the Dutch VAT}

There is wide agreement that the VAT is primarily a revenue-raising instrument that should be evaluated on the basis of its revenue performance. This is usually done by comparing actual VAT receipts with estimated potential receipts, which can be computed by applying the standard rate to the total final consumption expenditures of households, governments, and non-profit organizations. ${ }^{2}$ This ratio goes by the name of VAT collection efficiency, or C-efficiency for short. ${ }^{3}$ Obviously, the C-efficiency of a VAT that taxes all goods and services at a uniform rate equals 1 or, in other words, is $100 \%$. The Cefficiency is less than $100 \%$ if there is a policy gap or a compliance gap, as defined below.

\footnotetext{
* The authors are grateful for the perceptive comments of Johannes Hers and Judith Payne on an earlier version of the paper.

${ }^{1}$ For the latest consolidated version, see Council of the European Communities (2006).

2 This analysis is based on the anatomy proposed by Keen (2013).

${ }^{3}$ The C-efficiency is also called the VAT revenue ratio (VRR); see the discussion in OECD (2012, ch. 4).
} 


\subsection{C-Efficiency of the Dutch VAT}

As shown in table 1, the C-efficiency of the Dutch VAT was 54\% in $2010 .{ }^{4}$ This is higher than the C-efficiency of the EU-27 (without Croatia), which was on average approximately 50\% (CASE et al., 2013), but significantly lower than 100\%. In sharp contrast, the C-efficiency of the very modern New Zealand VAT was 99\% in 2010 (OECD, 2012), meaning that nearly all goods and services for final consumption were taxed at the uniform rate of $12.5 \%$.

\section{[table 1 about here]}

In 2010, the policy gap in the Dutch VAT was 44\% of potential receipts (see table 1). In the EU-26 (without Croatia and Cyprus), the average was 36\% (CASE et al., 2013). The policy gap denotes the revenue lost on account of the reduced rate and the exemptions. In the Netherlands, the nominal reduced rate of $6 \%$ is levied on foodstuffs, restaurant services, medical goods and dressings, transportation, reading matter, and some other goods and services. The exemptions for health and social care, education, and financial services attract a reduced effective VAT rate, because the sectors incur non-creditable VAT on taxable purchases. Similar to exemptions, government services are not taxable either (a feature that is called being 'out of scope') but the government is obliged to pay VAT on purchases.

In table 1, the components of the policy gap are computed by multiplying the VAT base relating to the reduced rate, exemptions, and out-of-scope governments by the standard rate (19\% in 2010) and reducing the amounts by, as appropriate, the revenue from the lower rate and the non-creditable VAT on the purchases of exempt entities and governments. The table indicates that the revenue lost on account of the exemptions and out-of-scope governments, at 33\%, is greater than the revenue lost due to the application of the reduced rate, which is $11 \%$. This suggests that eliminating the exemptions and reduced rate would involve an increase in VAT revenues. Of course, this need not be the case if the revenue increase were used to lower the standard rate after taking account of the increase in government expenditures on, for instance, higher subsidies for education and health care (to keep the nominal value of the charges constant) and the compensation of lower income groups, which would have to pay more VAT on goods and services that were previously taxed at the reduced rate.

The compliance gap is computed as the difference between the revenue that should be collected on the basis of existing VAT rules and actual revenue. The gap can be attributed to fraud, but also to bankruptcies, receiverships, and late payments. The VAT administration collects less VAT than indicated by the rules if, for instance, a bankrupt business is unable to remit its VAT even though it has collected the tax from its customers. In 2010, the compliance gap for the Netherlands was almost 5\% of VAT revenue, or $0.3 \%$ of GDP. ${ }^{5}$ This is low in comparison with the EU-26 average of $1.2 \%$ of the combined GDP (CASE et al., 2013). In view of the low Dutch gap, the costs of reducing it further would probably exceed the additional revenue. Also, as table 1 shows,

\footnotetext{
${ }^{4}$ The VAT revenues computed on the basis of CBS (2013) are less than the actual revenues shown in the national accounts ( $€ 42.7$ billion; CBS, 2010) on account of statistical discrepancies. The actual revenues result in a C-efficiency of $57 \%$.

${ }^{5}$ Note that in table 1 the compliance gap is expressed as a percentage of potential revenue in 2010 rather than the revenue that should have been collected on the basis of the existing rules.
} 
the compliance gap is small in comparison with the policy gap. For these reasons, it is not discussed further.

\subsection{Composition of the VAT Base}

Table 2 provides details of the composition of the VAT base - in other words, the policy gap. The total consumption expenditures of households and governments are shown in the first column under the heading 'Base modern VAT'. The heading 'Yield current VAT' shows the actual collections: 'output taxed' under the standard rate and the reduced rate, and 'input taxed' in the case of exempt sectors and governments with respect to intermediate goods and fixed assets. Effective tax rates can be computed by expressing the VAT thus collected as a percentage of the various consumption expenditure categories. The overall effective VAT rate is almost $11 \%$, and largely the same for households and governments. Compared with the standard rate, the varying effective tax rates are low for the exempt sectors and governments.

\section{[table 2 about here]}

The table clearly shows that the VAT is anything but a general, neutral tax on all final consumption expenditures. Little more than $40 \%$ of total consumption expenditures is taxed 'normally' (about two-thirds at the standard rate and one-third at the reduced rate), i.e. on sales of suppliers with a credit for the VAT on purchases. This means that almost $60 \%$ of the expenditures of households and governments is exempted or not taxed. To be sure, tax is paid 'indirectly' on intermediate goods and fixed assets, but this 'abnormal' form of taxation is in violation of one of the most basic economic principles - that consumers, not producers, should be taxed (Diamond and Mirrlees, 1971). Under a modern VAT, medical care, education, banks and insurance companies, and governments would all be taxed on their output instead of their inputs as is the case in the EU. Successive sections of this paper discuss the distortions and administrative problems of the exemptions, out-of-scope governments, and the reduced rate in greater detail.

\section{Exemptions and Out-of-Scope Governments}

On the basis of the common directive, the Netherlands has to exempt specified sectors and activities from VAT, such as health and social care, education, immovable property, financial services and insurance, games of chance, postal services, radio and television broadcasts, sociocultural institutions, and sports organizations. ${ }^{6}$ Further, the directive provides exemptions for specified sectors, such as agriculture, fishing and animal husbandry (the agricultural exemption), and small businesses (the small-business exemption or threshold), which cannot be changed after they have been agreed with the European Commission. Finally, similar to exemptions, the non-commercial activities of governments and other public bodies are 'out of scope' regarding the application of the VAT.

As is well known, the supply of exempt goods and services is not taxed (and suppliers are not allowed to charge VAT to customers), but the VAT on taxable purchases is not

\footnotetext{
${ }^{6}$ These exemptions, which violate the logic and functionality of the VAT, were incorporated in the common directive, because they also existed under the old turnover taxes, on account of their perceived favorable impact on the distribution of the tax burden, and because a number of technically complex activities were not understood well enough at the time to enable the VAT to be applied in practice. For a review and discussion, see De la Feria and Krever (2013).
} 
creditable either. Whether the exemptions increase or reduce VAT revenue depends on the stage at which they are applied. Exemptions of supplies that are rendered directly to consumers, called B2C supplies (for example, sporting events), reduce revenue. However, exemptions of intermediate or B2B supplies (financial services, for instance) should increase revenue due to the cascading (tax-on-tax) effect of the non-creditable VAT paid on purchases by the exempt entity, which is included in the price of the services that the entity provides.

\subsection{Economic Distortions}

Exemptions (and out-of-scope supplies) violate the neutrality criterion and hamper the workings of the VAT. The most important effects are the following. ${ }^{7}$

First, because the VAT on taxable purchases cannot be credited (washed out), exempt entities tend to substitute these purchases by lower-taxed or non-taxable goods and services. In other words, the exemption distorts input choices. Likewise, to the extent that the VAT on purchases cannot be passed on, it reduces the rewards of the factors involved in producing the supply. If a B2C supply is exempt (in other words, favorably treated relative to fully-taxed goods and services), then consumers will buy more of the exempt supply than they would in the absence of the exemption, and the producer will produce more of the exempt supply. If the exemption is of the intermediate B2B type, then the sale price will be higher or the net reward of the production factors lower on account of the non-creditable VAT. In most cases, both effects should occur; they would not necessarily be confined to the exempt supply but could work their way through the entire productiondistribution chain. The effects tend to be capricious and indeterminate regarding final prices and rewards of production factors.

Analogous to the distortion of input choices, exempt entities will try to avoid the tax on taxable purchases by performing in house various activities that would normally be outsourced. It is precisely this effect that the VAT is meant to prevent, because it discourages specialization. Administrative activities, IT, cleaning, catering, and safetyprovision services are examples of this form of uneconomical integration. The do-ityourself effect will be greater for low-taxed supplies (for example, catering or repair and maintenance) for which high-taxed inputs (pots and pans or windowsills, for instance) are used. Further, taxable firms should be less inclined to conduct research through, say, hospitals and universities, because these exempt entities cannot pass on the VAT on their inputs.

Second, international trade will be distorted. The VAT follows the destination principle, i.e. prior-stage VAT is refunded at export and imports are included in the base. As a result, relative prices are unaffected; the VAT does not hinder the competitive position of national firms in international markets. Exemptions of financial services and insurance, for instance, violate the destination principle, because the supplying firms are stuck with the VAT on their inputs, which increases their export prices or reduces factor rewards. Further, firms will tend to import exempt services if these are not subject to tax abroad or if the VAT is refunded at export by foreign VAT administrations. In the EU, the VAT of exempt financial services supplied to other member states is not refunded, but firms are

\footnotetext{
${ }^{7}$ See Ebrill et al. (2001), on which this discussion draws.
} 
eligible for refunds on exports to third countries. This forms an artificial incentive for exempt entities to channel their exports to other member states through third countries.

Third, exemptions will invite tax avoidance. Lobby groups will push for an extension of exemptions to suppliers and customers of exempt entities. Although the reach of these lobby groups is probably limited in the EU because the exemptions have been harmonized, nevertheless they can still argue for favorable interpretations and applications that expand the effective scope of the exemptions. Exemptions also form an incentive to avoid the VAT - for instance, by converting the (exempt) lease of immovable property into an agreement for the (taxable) storage of goods, so that the VAT-liable purchaser can credit the input tax against the VAT on his own sales. Finally, the correct attribution of the VAT on inputs to taxable and exempt supplies, when required, could form a potential bone of contention between exempt entities and VAT administrations. An example is the provision of taxable accounting and advisory services by exempt banks.

Last but certainly not least, leaving 'non-commercial' activities of governments out of scope should distort competition because governments can offer their goods and services at a lower VAT-inclusive price than private suppliers. The common directive mentions a number of goods and services that should always be taxed, but various services that can be equally well performed by the private sector remain out of scope. Municipal garbage collection is one of the standard examples.

\subsection{Exempt Services and Sectors}

The exemptions for health services, social care, and education figure prominently in the list of exemptions. It is often argued that these services generate (possibly) positive internal and external effects, which justify the exemption. Presumably, the same argument can be used to exempt sociocultural institutions, cooperative arrangements, and sporting organizations. But even if the merit-good argument is acknowledged, full taxation (inclusive of subsidies, if any) in combination with increased subsidies could leave the charge for the service (previously exempted) unaffected without, however, distorting the exempt entity's input choices and outsourcing policies and without discriminating against similar taxable services provided by the private sector (which should also be subsidized). Modern VATs therefore tax all of these services (albeit sometimes at a zero rate), which make an important contribution to GDP.

Perhaps even more important is the rather generous exemption of financial services, for which the value of intermediation services, embedded in interest rates, returns, or rewards, cannot be attributed to customers on a transaction-by-transaction basis, which is necessary if the VAT is to be passed on to VAT-liable businesses. For this reason, financial services are exempted from VAT in nearly all countries (or, exceptionally, their value added is taxed as the sum of wages and business cash flow). But countries with a modern VAT have a much less generous exemption than the EU. Thus, the exempt services of brokers and agents, the administration of investment funds, and explicit charges for banking services are all taxed in India, New Zealand, Singapore, and South Africa. What is probably the second-best solution is found in Australia, New Zealand, and Singapore, which apply a zero rate to B2B banking services (to avoid cascading) but exempt B2C 
banking services (to charge some VAT, even if indirectly). ${ }^{8}$ Currently, this solution is considered best practice, although the literature has developed more neutral but at the same time more complicated solutions. ${ }^{9}$

Separate mention should be made of the EU exemption of insurance services. General insurance, i.e. property and casualty insurance, is included in the base of all modern VATs by taxing premiums and providing a reverse credit for indemnity payments, which VATliable businesses have to include in their returns and which individuals can use to pay the VAT on purchases of replacements. ${ }^{10}$ As a result, only the value added by the insurance company (in the form of salaries and organization and marketing expenses) is taxed with a credit for the VAT on purchases. This method is difficult to apply to life insurance, however, which has a significant savings element. But for this form of insurance, value added could be calculated as the sum of wages and business cash flow. Cascade effects should hardly occur because life insurance policies are mainly taken out by individuals. If property and casualty insurance were brought into the VAT base, the distortionary Dutch insurance tax levied at a rate of $21 \%$ should be abolished. Finally, it should be noted that games of chance can be brought into the VAT base in similar fashion to insurance services by taxing stakes and paying out winnings inclusive of the VAT that can be attributed to them.

The VAT treatment of immovable property can be improved by withdrawing the exemption (and option for VAT registration) for properties that are not used as dwellings and bringing these properties fully into the VAT base. Newly-created property (and repair and renovation) would continue to be taxable. The VAT on these transactions would then be creditable for VAT-liable firms, but not for individuals and exempt entities. Again, this approach is characteristic of modern VATs. ${ }^{11}$

A modern VAT does not exempt agricultural activities as permitted under the common directive. At the time the VAT was introduced in the EU, its application to the agricultural sector was not considered opportune, because most farmers did not keep proper records. To eliminate the cascading effect of the exemption, buyers of agricultural products were given a presumptive VAT credit for the tax that was assumed to be paid by exempt farmers on taxable inputs. An option for registration and payment of VAT was made available for capital-intensive and exporting agribusinesses.

The agricultural exemption is an opaque way of eliminating the effect of the VAT on taxable purchases, which lends itself to implicit subsidization. Full taxation, as in Denmark, Sweden, and countries with a modern VAT, would be desirable, subject to an adequate threshold. A problem is that the (small-business) threshold is way too low in the Netherlands. In fact, it does not exist because the VAT has to be computed virtually regardless of the level of turnover and is then waived for low amounts of tax. To reduce the compliance cost of small businesses that this entails, an exemption of approximately

\footnotetext{
${ }^{8}$ See Pallot (2011) for a description of New Zealand practices. Reference should also be made to a proposal of the European Commission (2007) intended to improve the workings of capital markets and the competitive position of European financial institutions in international markets. In commenting on the Commission's proposals, De la Feria and Lockwood (2010, p. 171) argue that they 'would give rise to considerable interpretative and qualification problems, resulting in as much complexity and legal uncertainty as the current [exempt] regime'.

${ }^{9}$ See, especially, the pioneering contribution by Poddar and English (1997).

${ }^{10}$ See Cnossen (2013) for a detailed analysis and evaluation of the EU situation.

${ }^{11}$ For an extensive discussion of the current and best-practice treatment of immovable property in the EU, see Cnossen (2011).
} 
$€ 100,000$ turnover would seem appropriate. ${ }^{12}$ Interestingly, an exemption of this size would hardly affect revenue, because exempt small businesses would continue to pay VAT on their purchases. The higher threshold should have a progressive effect on the distribution of the tax burden, if it is assumed that small businesses, whose value added consists of the labor income of the owner and whose compliance costs are disproportionately large, are mainly found in low income groups.

\subsection{Public Bodies}

Public bodies that act as governments are not liable to tax under the common directive; they are considered 'out of scope'. A supply by government is only subject to VAT if nontaxation would involve a competitive distortion of some significance - a criterion that is difficult to apply. The common directive mentions a number of supplies that, if performed by public bodies, should always be considered taxable. These supplies include telecommunication services, goods transport, port and airport services, the supply of gas, water, and electricity, and the conveyance of passengers. In addition, jurisprudence shows that a government is deemed to act as government when it issues passports but not, for instance, when it sells compost. Further, the European Court of Justice has ruled that a government does not perform an economic activity when it issues permits for Universal Mobile Telecommunications Systems (UMTS).

The expanding interrelationships between public and private activities make it increasingly difficult to say whether or not a government acts as government and whether or not competition is distorted. Many government activities can be performed equally well by the private sector. And even if this is not the case, the exemption of public bodies still generates distortions of input and outsourcing choices, which harm competition too. ${ }^{13}$

For these reasons, public bodies are taxed much more widely under modern VATs than is the case in the EU. ${ }^{14}$ This can be done in three ways: (a) exemption, but much more restricted than is currently the case; (b) refund of the VAT paid on taxable purchases, which should eliminate input and outsourcing distortions but not unfair competition (because VAT would continue to be levied on similar supplies made by the private sector); and (c) full taxation of the supplies made by public bodies. New Zealand has opted for the last approach, under which the approved expenditure allocations in the government's budget are the consideration against which the supplies are performed. Further, VAT is imposed on levies, subsidies, grants, and local taxes. Australia treats the supplies of public bodies in similar fashion. On account of its complex federal structure, which, for instance, does not permit the federal government to tax subordinate governments, Canada refunds nearly the whole federal VAT collected on the inputs of municipalities, academic institutions, schools, and hospitals (the so-called MASH sector). Incidentally, all of these countries treat non-profit organizations similarly to public bodies.

In some EU countries, including the Netherlands, an attempt is made to reduce the distortion of subsidiary governments' outsourcing choices through a compensation fund. Municipalities, provinces, and some other bodies can apply for a refund of the VAT attributable to governmental and non-commercial activities. The fund is not integrated

\footnotetext{
${ }^{12}$ For the calculation of the most appropriate exemption, see Keen and Mintz (2004).

${ }^{13}$ The (unnecessarily) complicated legal and procedural rules and the complex jurisprudence around the VAT treatment of public bodies are analyzed by De la Feria (2009).

${ }^{14}$ For an extensive analysis of the VAT treatment of public bodies in the EU, Australia, Canada, and New Zealand, see Gendron (2013).
} 
with the VAT but reduces the burden of the tax, so that subsidiary governments can make a less distorted choice between outsourcing and the in-house performance of activities. This form of selective compensation causes new distortions, however - for instance, because the price difference (inclusive of VAT) vis-à-vis activities that can also be performed by the private sector becomes even larger. ${ }^{15}$ Incidentally, this is also the case in Canada.

The taxation of as many supplies by public bodies as possible promotes simplicity, accountability, transparency, and the workings of the VAT. Delineation issues regarding taxable versus non-taxable activities become redundant and the VAT chain remains intact through to the consumer level. Distortions of input and outsourcing choices are reduced and so are administrative costs because the VAT on taxable purchases does not have to be allocated between taxable and exempt supplies. Although public bodies do not pursue profit maximization, cost minimization is their aim and this goal is promoted by applying the VAT as widely as possible.

\subsection{How Large Is the Efficiency Gain?}

Copenhagen Economics (2013) has calculated the efficiency gain that could be reaped if government activities and exempt supplies were taxed (with credit for the VAT on intermediate goods and fixed assets). It analyzed the effects of six core services, i.e. cultural activities, education, health care, garbage collection, postal services, and radio and television broadcasts, which, jointly, contribute $14.2 \%$ of GDP in the EU-27. The efficiency gain of fully taxing these services, which is what New Zealand does, would be $0.34 \%$ of GDP, while the alternative of refunding input taxes would produce a gain of merely $0.02 \%$. Full taxation should have a significant positive effect on medium-sized and small businesses, which account for $60 \%$ of business services in these sectors. In view of the harmonized exemptions, it may be assumed that the Netherlands should be able to record a similar efficiency gain. Not surprisingly, Copenhagen Economics concludes: 'we recommend to look towards a full taxation solution' (p. 12). ${ }^{16}$

\section{The Reduced Rate}

Like exemptions, reduced rates are anathema to a modern VAT. The arguments for and against reduced rates have repeatedly been the subject of debate (Copenhagen Economics, 2007; Crawford, Keen, and Smith, 2010). This section reviews them and simulates the adoption of a uniform rate for the Dutch situation.

\subsection{Arguments for a Reduced Rate}

Reduced rates can be rationalized on the basis of at least four arguments:

- Essential goods and services, disproportionately consumed by the poor, should be taxed at a reduced rate. ${ }^{17}$

- A reduced rate can be used to correct for the distortions of the income tax.

\footnotetext{
${ }^{15}$ See, for example, Wassenaar and Gradus (2004), who review and evaluate the compensation mechanisms in Denmark, Finland, the Netherlands, Norway, Sweden, and the United Kingdom.

${ }^{16}$ Copenhagen Economics (2013) rightly notes that public bodies could avoid the VAT by transforming product subsidies (taxable under the common directive) into budget subsidies (not taxable). Therefore, budget subsidies should also be included in the taxable price, which is what modern VATs do.

${ }^{17}$ We ignore the arguments for a higher-than-standard rate on luxury goods. The case for trying to increase the progressivity of the tax system in this way is weak even in developing countries.
} 
- To stimulate employment, labor-intensive services should be taxed at a lower rate.

- A reduced rate discourages the consumption of merit goods less than a standard rate would.

Reducing regressivity The spending patterns of individual households can be used to evaluate the argument that a lower rate reduces the regressivity of the distribution of the VAT burden. The most recent usuable budget survey for the Netherlands, which took place in 2004, provides information on the distribution of different expenditures over various income deciles. After adjusting the incomes and expenditures for the size and composition of households, ${ }^{18}$ the households are divided into 10 income groups or deciles based on their 'normalized' disposable incomes. As is often done, the first and last deciles are left out of consideration because the data for them tend to be less reliable. Figure 1 shows that the share of household budgets spent on product categories subject to the reduced rate does not differ much between income groups. Further, in comparison with the second decile, the ninth decile spends relatively more (5 percentage points) on categories subject to the standard rate and somewhat less (4 percentage points) on exempt categories.

\section{[figure 1 about here]}

Differences in VAT burdens between lower and higher income groups can also be expressed through what is called the effective VAT rate, i.e. total VAT payments of a normalized household as a percentage of disposable income (excluding income tax and VAT). As shown in the left panel of figure 2, the VAT burden drops slightly from decile 2 onwards as disposable income increases. In other words, the figure suggests that the distribution of the VAT burden is regressive: as a percentage of disposable income, the effective VAT burden is lower for higher than for lower incomes.

\section{[figure 2 about here]}

In calculating the VAT burden distribution, disposable income is usually taken as the denominator. However, total consumer spending net of VAT is a better alternative because it varies less than income over the life cycle of the individual. Periods with lower incomes are generally followed by periods with higher incomes (students and temporarily unemployed people, for example) and the other way around (the elderly, for instance). Therefore, consumption expenditures are a more stable denominator than income is. If the VAT burden is expressed in terms of expenditures, its impact is slightly progressive (see right panel of figure 2). Similar results have been found for other EU member states (Institute for Fiscal Studies et al., 2011).

The conclusion that higher income groups spend relatively as much on goods and services subject to the reduced rate as lower income groups implies that they spend more in euro terms. In 2004, a household in the ninth decile spent 1.8 times more on reduced-rated goods per (equivalent) person than a household in the second decile (a similar relationship was found for the spending deciles). This means that in euro terms, higher income groups benefited 1.8 times more from the reduced rate than lower income groups. Higher income groups buy more expensive varieties of foodstuffs, eat out more often, throw more food

\footnotetext{
${ }^{18}$ All expenditures are divided by the CBS equivalence ratio. This ratio varies from 1.00 to 2.61 and is on average 1.48 . The ratio equals 1.00 for a single adult and 1.37 for a household of two adults without children; it increases to 1.88 for a household of two adults and two minors.
} 
away, buy more periodicals and books, and visit museums and concerts more often, etc. Accordingly, the reduced rate is an ill-targeted instrument to mitigate the VAT burden on lower income groups. Moreover, the revenue loss from having the lower rate is significant (more than $€ 8$ billion in the absence of behavioral effects; 3.7×(19-6)/6 from table 1) and the redistribution that is realized is small (see figure 2). The income tax and the social benefit system are much more effective alternatives for influencing the distribution of the tax burden. ${ }^{19}$

Mitigating income tax distortions A second argument in favor of a reduced rate is that it can mitigate the distortionary effects of the income tax. The tax on wages influences labor supply decisions by making leisure more attractive. To correct for this effect, goods consumed complementary to paid work could be taxed lower than goods consumed complementary to leisure. Estimates for the UK show that an increase in hours of paid work is accompanied by an increase in the share of expenditures on, for instance, restaurants and motor fuel (Crawford, Keen, and Smith, 2010). This relationship can also be reversed: a lower rate on the consumption of restaurant meals and gasoline stimulates labor supply. An opposite relationship is found for expenditures on home food, lighting, and heating. From this perspective, home food should not be taxed at the lower rate.

Calculating the rates that correct for labor supply effects, however, requires a much deeper knowledge of the relationship between the consumption of specific goods and labor supply than is currently available. Generally, the expected welfare gain from rate differentiation should be small, because the complementarity between consumption and time spent on paid work is weak. Further, implementing this kind of rate differentiation would be quite complicated. What can be said, however, is that it seems that many goods and services that are subject to the lower rate are not complementary to paid work. By itself, this is an argument for reconsidering the role of the reduced rate.

Stimulating labor supply The third argument is related to the second: the taxation of labor-intensive services (such as garden and home maintenance and repair activities) stimulates do-it-yourself substitution. In the absence of the VAT, a professional supplier might be able to provide these services more cheaply. Do-it-yourself activities come at the expense of leisure (assuming that this is appreciated more than performing jobs in and around the house) or the supply of paid work in the labor market. The reduced rate could be used, therefore, to stimulate the supply of market-based labor-intensive services. Apart from tax avoidance, the VAT on these forms of consumption expenditures can also induce tax evasion.

The problem of this use of the reduced rate is that it is difficult to give a precise taxrelevant definition of price-sensitive labor-intensive services. Also, the VAT can leak away if the VAT on higher-taxed purchases (for example, paint) is credited against the VAT on lower-taxed services (painting, for instance). If combating tax evasion is a supplementary goal, then the VAT rate is less important than the much higher income tax rate. In the event, a lower income tax rate on labor-intensive services would be a more appropriate way to stimulate market-based labor-intensive work, although this would bring its own administrative complications.

\footnotetext{
${ }^{19}$ For an early but useful illustration of switching from the VAT to these alternatives, see Hemming and Kay (1981).
} 
Favoring merit goods The last argument concerns the imposition of a reduced rate on the consumption of merit goods, whose intrinsic value tends to be underestimated by consumers. Therefore, the argument goes, governments should stimulate the consumption of goods and services such as education, health care, books, journals, and cultural events. In the same way that excises are employed to discourage the consumption of goods that cause negative externalities (such as pollution), a reduced VAT rate could be used to stimulate the consumption of merit goods. Again, however, the VAT is not an appropriate instrument to correct prices for positive internal and external effects. Targeted subsidies should be used for that purpose because they land where the social return is highest.

To conclude, serious doubts can be raised about the suitability of the reduced rate to reduce the VAT's regressivity, mitigate income tax distortions, stimulate labor supply, or favor merit goods.

\subsection{Arguments for a Uniform Rate}

The theoretical literature shows that the application of a uniform rate is optimal, but also that this result is subject to quite stringent conditions. The practical arguments in favor of a uniform rate are so strong, however, that this is usually regarded as 'best practice' (Keen, 2013). ${ }^{20}$

The first advantage of a uniform rate is that it does not distort consumer and producer choices; relative prices stay the same. To illustrate, assume that without VAT a consumer prefers good A over good B, which is equally expensive. Next, good A is taxed more heavily than good B and the consumer buys good B instead of good A. In the event, a welfare loss arises, because the choice between $\mathrm{A}$ and $\mathrm{B}$ is not determined by the consumer's preference but by the difference in tax. Eliminating the reduced rate therefore involves a welfare gain. Consumers will not consume more of a product on account of the lower rate and producers will not produce more of that product. In short, everyone will be better off with a uniform standard rate, particularly if all households are compensated for the loss in disposable income (Crawford, Keen, and Smith, 2010).

The Institute for Fiscal Studies et al. (2011) have quantified the potential welfare gain from rate unification for the UK and Belgium (regrettably, no analysis has been done for the Netherlands). An increase in the reduced rates (including the zero rate on food and dwellings in the UK) to the level of the standard rate implies a welfare gain of $3.5 \%$ of total VAT receipts in the UK. ${ }^{21}$ The welfare gain for Belgium is even greater, at $4.6 \%$. In an alternative scenario, the elimination of the reduced rate is combined with a reduction of the standard rate by 5 percentage points, so that VAT yields stay the same. This results in a welfare gain per household of $€ 1.07$ per week in the UK and $€ 0.74$ per week in Belgium. Plausibly, a similar welfare gain would be realized for the Netherlands, because the differentiated rate involves roughly the same revenue loss as in Belgium (Keen, 2013).

A second advantage of a uniform rate is that it contributes to a simpler tax system with lower administration and compliance costs. For 2007, the VAT compliance costs for the Dutch business community were estimated at $€ 408$ million (excluding costs of invoicing;

\footnotetext{
${ }^{20}$ Therefore we ignore the well-known Ramsey rule that distorting effects can be minimized by taxing price-elastic goods (such as caviar) at a low rate and price-inelastic goods (bread, for instance) at a high rate.

${ }^{21}$ The study expresses the welfare gain in terms of VAT revenues, whereas the efficiency gain from eliminating the exemptions was expressed in terms of GDP in section 3.4 of this paper.
} 
Studiecommissie belastingstelsel, 2010). The Ministry of Finance (Ministerie van Financiën, 2008) estimated that a uniform VAT rate would reduce these costs by some $€ 100$ million. Also, the direct administrative costs of the VAT, estimated at $€ 138$ million, would go down. Compared with a dual rate structure, a uniform rate is also less sensitive to lobbying activities, while misclassifications, intentional or not, should not occur. The introduction of a uniform rate therefore reduces not only the policy gap but also the compliance gap. $^{22}$

\subsection{Simulation of a Uniform Rate}

The distributional effects of adopting a uniform rate can be illustrated with the aid of a microsimulation model based on the observed outlays of 1,570 households on 135 categories of goods and services in 2004 taken from the most recent usable budget survey for the Netherlands. The analysis is static in the sense that it is assumed that the outlays exclusive of VAT stay constant after rate unification. No account is taken of behavioral responses to price adjustments or of effects on cross-border shopping. The effects are weighted by the share of each type of income-differentiated household in the total population. Further, it is assumed that the rate changes are passed on fully in consumer prices, i.e. prices exclusive of VAT stay constant. These kinds of calculations and the attendant assumptions are used in many empirical studies. ${ }^{23}$

The simulation investigates the adoption of a revenue-neutral uniform rate while maintaining the exemptions. (The elimination of the exemptions is difficult to simulate because (public) expenditures on care and education are not shown in household budgets.) This uniform rate, computed as the ratio of total VAT revenue to the actual VAT base, was $15.6 \%$ in $2004 .{ }^{24}$ This implies that the reduced rate increases by 9.6 percentage points, while the standard rate drops by 3.4 percentage points. Since households spend a larger share of their outlays on goods and services subject to the reduced rate than other entities that pay VAT, the former are confronted with an average increase in the effective VAT burden of 0.8 percentage points. ${ }^{25}$ Figure 3 shows that rate unification makes the distribution of the VAT burden less progressive: households with low (equivalent) outlays are confronted with a greater increase in the effective tax rate than households with high outlays. The increase in the effective rate is highest for the second decile, at 1.3 percentage points, but merely 0.6 points for the ninth decile.

\section{[figure 3 about here]}

\section{Conclusions}

Table 3 provides a summary of the current Dutch VAT treatment and the modern VAT treatment of reduced rates and exempt goods, services, and sectors. The neutrality of the

\footnotetext{
${ }^{22}$ A disadvantage of abolishing the reduced rate is that Dutch inhabitants of border areas might buy their foodstuffs in Belgium and Germany. On the other hand, the lower Dutch standard rate would attract Belgian and German buyers for other products. In any event, cross-border purchases are more of a problem for excisable goods than for goods and services subject to VAT. See the overview in Cnossen (2003).

${ }^{23}$ Mellens and Dijkstra (2013) conclude that the VAT increase in The Netherlands in October 2012 had been fully passed on into consumer prices by March 2013. The Institute for Fiscal Studies et al. (2011) discuss studies for other countries.

${ }^{24}$ The latest available macro data result in the same uniform rate for 2010 (CBS, 2010). After the increase of the standard rate by 2 percentage points in 2012, the revenue-neutral rate increases to $17 \%$ under the assumption of constant shares of the rates in total consumption, i.e. $26.5 \%$ for the reduced rate and $73.5 \%$ for the standard rate.

${ }^{25}$ The paper assumes that the consequences of the rate adjustments for entities other than households are not passed on to the latter. For example, the sale prices of exempt entities are assumed to remain constant even if they have to pay more VAT on their inputs.
} 
Dutch VAT and, by extension, the European VAT can be improved considerably by abolishing the reduced rate (while compensating lower income groups through the income tax and the social benefit system, if desired) and by eliminating or reducing the exemptions. The reduced rate is a highly ineffective instrument for influencing the distribution of the VAT burden in favor of lower income groups. The exemptions, including out-of-scope activities, distort input and outsourcing choices of exempt entities. Exemptions tend to result in the overtaxation of businesses and the undertaxation of consumers. Exempt and out-of-scope entities can also harm the competitive position of private businesses.

\section{[table 3 about here]}

The total picture of the distortions and the unnecessary complexity of the Dutch and EU VAT is highly disconcerting when compared with the modern VATs that are levied elsewhere in the world. Basically, the common directive has institutionalized the shortcomings of the original VAT, which was designed at a time when the logic and functionality of the VAT were scarcely out of the egg. Now, changes - even of a single comma - require the approval of all member states. Perhaps member states should be given the authority to change their own VAT in any way that would make it better than the VAT embodied in the common directive.

Sijbren Cnossen

Tapijtweg 7

2597 KG The Hague

The Netherlands

cnossen@ese.eur.nl 


\section{References}

CASE, CPB, CAPP, CEPII, ETLA, IFO, IFS, and IHS (2013), Study to Quantify and Analyse the VAT Gap in the EU-27 Member States, study commissioned by the European Commission, DG TAXUD. [link]

CBS (2010), Nationale Rekeningen 2010, The Hague.

CBS (2013), Bestedingscategorieën (excl. BTW) 2010 Ingedeeld naar BTW-tariefgroepen 2012, Memorandum.

Cnossen, S. (2003), Is the VAT’s Sixth Directive Becoming an Anachronism? European Taxation 43, 434-442.

Cnossen, S. (2011), A Proposal to Improve the VAT Treatment of Housing in the European Union, Fiscal Studies 32, 455-481. Reprinted as chapter 7 in: de la Feria, R. (Ed.), VAT Exemptions: Consequences and Design Alternatives, Wolters Kluwer, Law and Business, Alphen aan de Rijn, The Netherlands, 225-252.

Cnossen, S. (2013), A Proposal to Apply the Kiwi-VAT to Insurance Services in the European Union, International Tax and Public Finance 20, 867-883.

Copenhagen Economics (2007), Study on Reduced VAT Applied to Goods and Services in the Member States of the European Union: Final Report, European Commission, Brussels. [link]

Copenhagen Economics (2013), VAT in the Public Sector and Exemptions in the Public Interest: Final Report for TAXUD/2011/DE/334, European Commission, Brussels. [link]

Council of the European Communities (2006), Council Directive 2006/112/EC of 28 November 2006 on the Common System of Value Added Tax. [link]

Crawford, I., Keen, M., and Smith, S. (2010), Value Added Tax and Excises, chapter 4 in: Mirrlees, J., Adam, S., Besley, T., Blundell, R., Bond, S., Chote, R., Gammie, M., Johnson, P., Myles, G., and Poterba, J. (Eds.), Dimensions of Tax Design: The Mirrlees Review, Oxford University Press, Oxford, 275-362. [link]

De la Feria, R. (2009), The EU VAT Treatment of Public Sector Bodies: Slowly Moving in the Wrong Direction, Intertax 37, $158-196$.

De la Feria, R., and Krever, R. (2013), Ending VAT Exemptions: Learning from Experience, Towards a Post-Modern VAT, chapter 1 in: de la Feria, R. (Ed.), VAT Exemptions: Consequences and Design Alternatives, Wolters Kluwer, Law and Business, Alphen aan de Rijn, The Netherlands, 3-36.

De la Feria, R., and Lockwood, B. (2010), Opting for Opting-In? An Evaluation of the European Commission’s Proposals for Reforming VAT on Financial Services, Fiscal Studies 31, 171-202.

Diamond, P. A., and Mirrlees, J. A. (1971), Optimal Taxation and Public Production, I: Productive Efficiency, American Economic Review 61, 8-27.

Ebrill, L., Keen, M., Bodin, J-P., and Summers, V. (2001), The Modern VAT, International Monetary Fund, Washington DC.

European Commission (2007), Proposal for a Council Regulation Laying Down Implementing Measures for Directive 2006/112/EC on the Common System of Value Added Tax, as regards the Treatment of Insurance and Financial Services, COM(2007) 746 final (28 November), Brussels. [link]

European Commission (2010), Green Paper on the Future of VAT: Towards a Simpler, More Robust and Efficient VAT System, COM(2010) 695/4, Brussels. [link]

Gendron, P-P. (2013), VAT Treatment of Public Sector Bodies: The Canadian Model, chapter 3 in: de la Feria, R. (Ed.), VAT Exemptions: Consequences and Design Alternatives, Wolters Kluwer, Law and Business, Alphen aan de Rijn, The Netherlands, 103133.

Hemming, R., and Kay, J. (1981), The United Kingdom, in: Aaron, H. J. (Ed.), The Value-Added Tax: Lessons from Europe, Brookings Institution, Washington DC.

Institute for Fiscal Studies, CPB, CAPP, CASE, CEPII, ETLA, IFO, and IHS (2011), A Retrospective Evaluation of Elements of the EU VAT System, study commissioned by the European Commission (DG TAXUD). [link]

Keen, M. (2013), The Anatomy of the VAT, National Tax Journal 66, 423-446.

Keen, M., and Mintz, J. (2004), The Optimal Threshold for a Value-Added Tax, Journal of Public Economics 88, 559-576.

Mellens, M., and Dijkstra, J. (2013), Schatting Effect BTW-verhoging op Inflatie, CPB Background Document, 17 September, Den Haag. [link] 
Ministerie van Financiën (2008), Uniform BTW-tarief: Aspecten en Overwegingen in Kort Bestek, Letter to Parliament, 23 December. [link]

OECD (2012), Consumption Tax Trends 2012, Paris. [link]

Pallot, M. (2011), Financial Services under New Zealand’s GST, International VAT Monitor 5, 310-315.

Poddar, S., and English, M. (1997), Taxation of Financial Services under a Value-Added Tax: Applying the Cash Flow Approach, National Tax Journal 50, 89-111.

Studiecommissie Belastingstelsel (2010), Continuïteit en Vernieuwing, The Hague. [link]

Wassenaar, M. C., and Gradus, R. H. J. M. (2004), Contracting Out: The Importance of a Solution to the VAT Distortion, CESifo Economic Studies 50, 377-396. 
Table 1

The Netherlands: Composition of VAT Revenues in 2010

\begin{tabular}{lrr}
\hline & $€$ billion & \% \\
\hline Potential revenue = Standard rate (19\%) × Total final consumption & 74.7 & 100.0 \\
Policy gap & 33.0 & 44.2 \\
$\quad$ exemptions & $(19.6)$ & $(26.2)$ \\
$\quad$ out-of-scope governments & $(5.3)$ & $(7.1)$ \\
$\quad$ reduced rate & $(8.1)$ & $(10.9)$ \\
Revenue with full compliance & 41.6 & 55.7 \\
Compliance gap & 1.5 & 0.2 \\
C-efficiency & 40.1 & 53.6 \\
\hline
\end{tabular}

Source: CBS $(2010,2013)$ and CASE et al. (2013). 
Table 2

The Netherlands: Composition of the VAT Base in 2010

\begin{tabular}{|c|c|c|c|c|}
\hline \multirow[t]{2}{*}{ Consumption expenditures } & \multicolumn{2}{|c|}{ Base modern VAT } & \multicolumn{2}{|c|}{ Yield current VAT } \\
\hline & $\begin{array}{r}\text { Amount } \\
\text { ( } € \text { billion) }\end{array}$ & $\%$ of total & $\begin{array}{r}\text { Amount } \\
\text { ( } € \text { billion) }\end{array}$ & $\begin{array}{r}\text { Effective } \\
\text { tax rate } \\
(\%)\end{array}$ \\
\hline A. Households & 334.1 & 85.0 & 35.8 & 10.7 \\
\hline & & & \multicolumn{2}{|c|}{ Output taxed } \\
\hline Standard rate (19\%) & 102.6 & 26.1 & 19.5 & 19.0 \\
\hline Reduced rate (6\%) & 62.5 & 15.9 & 3.7 & 6.0 \\
\hline & & & \multicolumn{2}{|c|}{ Input taxed } \\
\hline Exempt sectors & 168.9 & 43.0 & 12.5 & 7.4 \\
\hline Medical and social care & $(61.7)$ & $(15.7)$ & $(2.6)$ & $(4.2)$ \\
\hline Rents and rental values & $(44.3)$ & (11.3) & $(-)$ & $(-)$ \\
\hline Lease/Trade in immovable property & $(-)$ & $(-)$ & $(5.5)$ & $(-)$ \\
\hline Education (including salaries) & $(30.0)$ & $(7.6)$ & $(1.1)$ & (3.5) \\
\hline Banks and insurance & $(20.5)$ & $(5.2)$ & $(2.3)$ & $(11.1)$ \\
\hline Sports, recreation, games of chance & (2.3) & $(0.6)$ & $(0.3)$ & $(10.8)$ \\
\hline Other goods and services & $(10.0)$ & $(2.5)$ & $(0.9)$ & $(8.9)$ \\
\hline B. Governments (except education) & 58.9 & 15.0 & 5.9 & 10.0 \\
\hline C. Total consumption expenditures & 392.9 & 100.0 & 41.6 & 10.6 \\
\hline
\end{tabular}

Source: See table 1. Total consumption expenditures are the amount shown in table G12 of CBS (2010) as reduced by the VAT in table D1.1. 
Table 3

Converting the Dutch VAT into a Modern VAT

\begin{tabular}{|c|c|c|c|c|c|}
\hline \multirow[b]{2}{*}{ Goods, services, and sectors } & \multicolumn{2}{|r|}{ Dutch VAT } & \multicolumn{2}{|c|}{ Modern VAT } & \multirow[t]{2}{*}{ Supplementary measures } \\
\hline & Treatment & Original argument & Treatment & Reasons & \\
\hline A. Reduced rate & & & & & \\
\hline 1. Foodstuffs & Reduced rate & Tax relief for lower income groups & Taxed at uniform rate & $\begin{array}{l}\text { Reduced rate is ill-targeted } \\
\text { instrument }\end{array}$ & $\begin{array}{l}\text { Adjustments of the income tax and the } \\
\text { social benefit system }\end{array}$ \\
\hline 2. Social and cultural services & Reduced rate & Positive internal and external effects & Taxed at uniform rate & $\begin{array}{l}\text { Reduced rate is ill-targeted } \\
\text { instrument }\end{array}$ & Possibly, increase in subsidy \\
\hline \multicolumn{6}{|l|}{ B. Exemptions } \\
\hline $\begin{array}{l}\text { 1. Health care, education, } \\
\text { social services }\end{array}$ & Exempt & Positive internal and external effects & Full taxation & $\begin{array}{l}\text { Reduced rate is ill-targeted } \\
\text { instrument }\end{array}$ & Increase in subsidy, if desired \\
\hline 2. Financial services & Exempt & $\begin{array}{l}\text { Added value difficult to determine on } \\
\text { a transaction-by-transaction basis }\end{array}$ & $\begin{array}{l}\text { Zero rate for B2B services } \\
\text { Exemption for B2C services }\end{array}$ & Greater neutrality & None \\
\hline \multicolumn{6}{|c|}{ 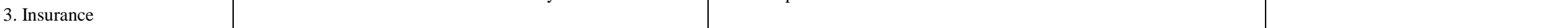 } \\
\hline a. Property and casualty & Exempt & Added value difficult to determine & $\begin{array}{l}\text { Tax on premiums and reverse } \\
\text { charge for payouts }\end{array}$ & Greater neutrality & Elimination of insurance tax \\
\hline b. Life and health & Exempt & Added value difficult to determine & $\begin{array}{l}\text { Tax on sum of wages and business } \\
\text { cash flow }\end{array}$ & Greater neutrality & None \\
\hline 4. Games of chance & Exempt & Added value difficult to determine & $\begin{array}{l}\text { Tax on stakes and reverse charge } \\
\text { on winnings }\end{array}$ & Greater neutrality & $\begin{array}{l}\text { Reduction of selective duties on games } \\
\text { of chance with revenue purpose }\end{array}$ \\
\hline 5. Immovable property & $\begin{array}{l}\text { Exempt, except if } \\
\text { newly created }\end{array}$ & $\begin{array}{l}\text { Rents and rental values difficult to } \\
\qquad \text { tax }\end{array}$ & $\begin{array}{l}\text { Full taxation, except sale of } \\
\text { dwellings, which are taxed only on } \\
\text { gain upon sale }\end{array}$ & Greater neutrality and fairer & Elimination of transfer duty \\
\hline \multicolumn{6}{|l|}{ C. Exempt sectors } \\
\hline 1. Agriculture & Exempt & Difficult to tax & $\begin{array}{l}\text { Full taxation with increased small- } \\
\text { business exemption }\end{array}$ & Greater neutrality & $\begin{array}{l}\text { Elimination of presumptive VAT credit } \\
\text { for buyers of agricultural products }\end{array}$ \\
\hline 2. Small businesses & $\begin{array}{l}\text { Reduction of tax } \\
\text { liability }\end{array}$ & Mitigation of VAT burden & Turnover exemption of $€ 100,000$ & $\begin{array}{l}\text { Reduction of administration and } \\
\text { compliance costs }\end{array}$ & None \\
\hline D. Public bodies & Out of scope of VAT & Act as government & Full taxation & Greater neutrality & Possibly, increase in budget allocation \\
\hline E. Out-of-scope supplies & Out of scope of VAT & Activities should not be taxed & Full taxation & $\begin{array}{l}\text { Absence of consideration or nature } \\
\text { of activity not a useful criterion }\end{array}$ & None \\
\hline
\end{tabular}


Figure 1

The Netherlands: Distribution of VAT Expenditure Categories (Excluding VAT) by Income Decile in 2004

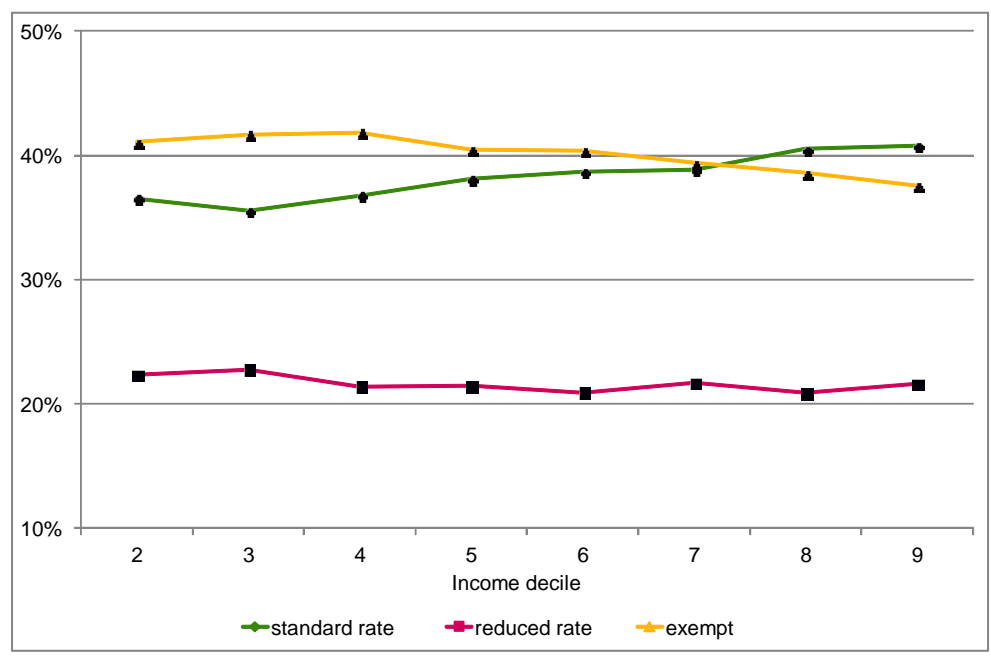


Figure 2

The Netherlands: Effective VAT Rates across Income and Spending Deciles in 2004
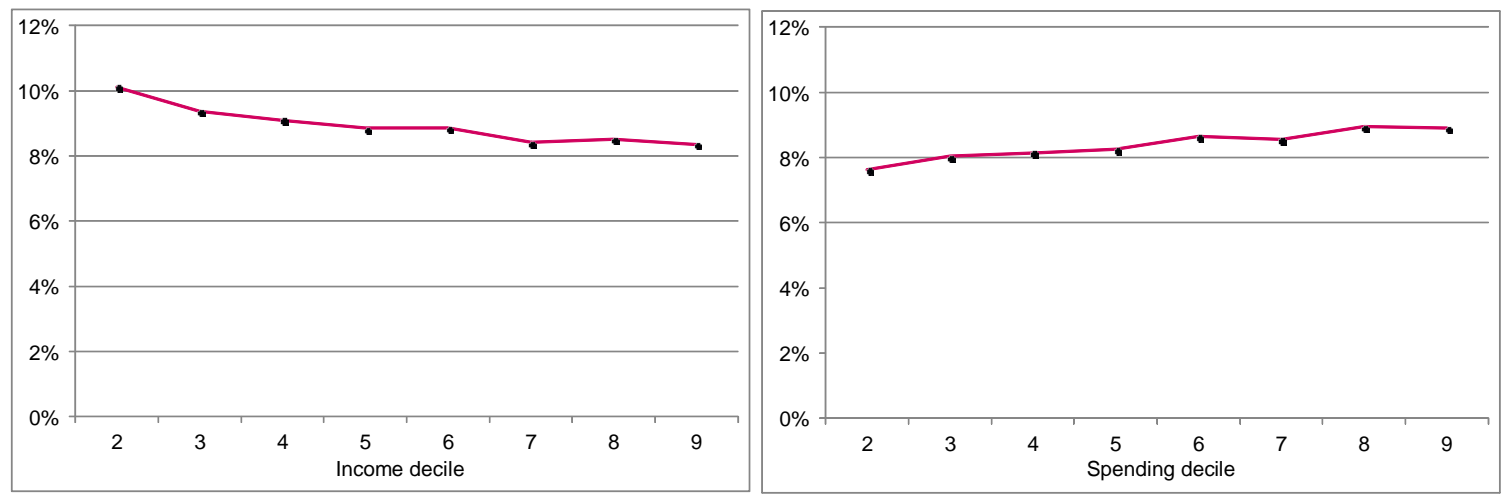
Figure 3

Increase in (left) and Level of (right) Households' Effective VAT Burden under a Uniform Rate of 15.6\%
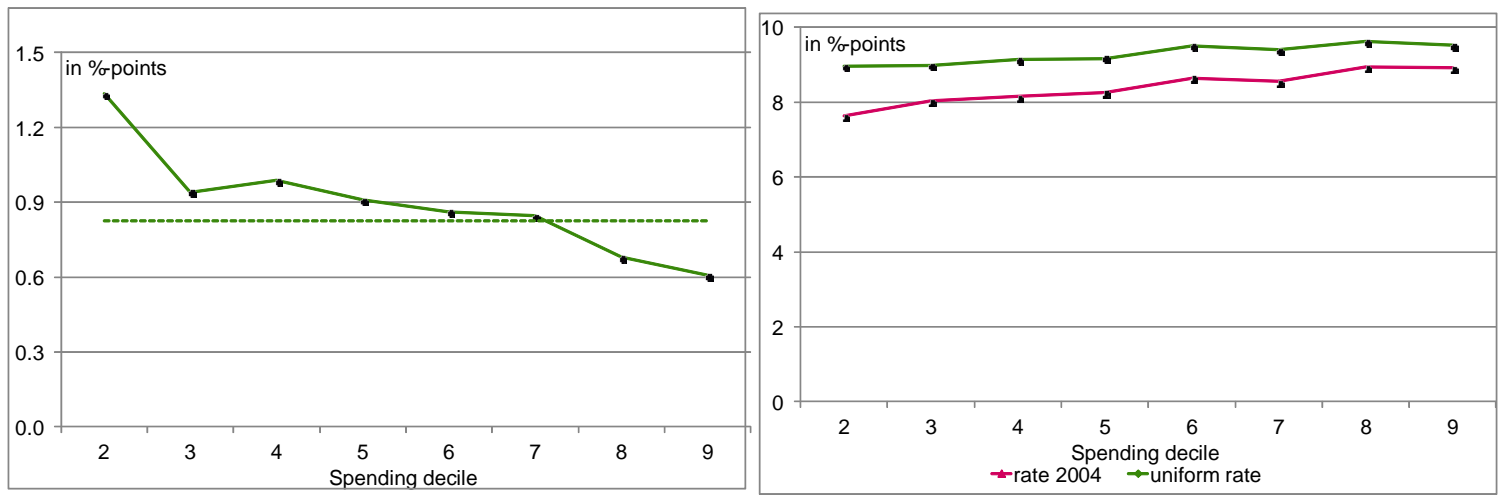